\title{
Effect of low cost mole drainage technology on yield of chickpea (Cicer arietinum L.) under waterlogged vertisols of Maharashtra, India
}

\author{
S.D. Rathod ${ }^{1 *}$, B.M. Kamble ${ }^{2}$ and D.K. Kathmale ${ }^{3}$ \\ (Maharashtra), INDIA \\ *Corresponding author. E-mail: sdrathod2004@gmail.com \\ Received: October 28, 2015; Revised received: March 17, 2016; Accepted: June 7, 2016
}

${ }^{1,2,3}$ Agricultural Research Station, Mahatma Phule Krishi Vidyapeeth, Kasbe Digraj, Dist. Sangli- 416305

\begin{abstract}
The field experiment was conducted on performance of mole drainage under irrigated and waterlogged vertisols of Maharashtra at Agricultural Research Station, K. Digraj, Dist. Sangli (M.S.), India during 2009-10 to 2011 -12. An experimental layout of different mole spacings viz. mole drainage (MD) with $2 \mathrm{~m}\left(\mathrm{~T}_{1}\right), 4 \mathrm{~m}\left(\mathrm{~T}_{2}\right), 6 \mathrm{~m}$ mole spacing $\left(T_{3}\right)$ and without drainage i.e. control $\left(T_{4}\right)$ in a randomized block design with five replications. The results revealed that the weighted means of yield attributing parameters of chickpea and pooled mean of chickpea yield recorded highest in MD with $4 \mathrm{~m}$ mole spacing and which was at par with $6 \mathrm{~m}$ mole drain spacing as compare to control plot (without mole drainage). The MD with $2 \mathrm{~m}$ mole spacing recorded significantly lowest chickpea yield among mole drained plots which was at par with control. This study indicated that the MD with $4 \mathrm{~m}$ mole spacing is recommended for economically feasible production of chickpea under irrigated and waterlogged vertisols of Maharashtra.
\end{abstract}

Keywords: Chickpea, Economic feasibility, Mole drainage, Mole spacing and Vertisols

\section{INTRODUCTION}

The cultivated productive soil is affected due to water logging, soil salinity and sodicity problems after introduction of irrigation. The area under salinization and alkalinisation in India were estimated at 2.96 and 3.77 Mha respectively; whereas in Maharashtra these were estimated at 0.184 and 0.423 Mha respectively (CSSRI, 2007). About $30 \%$ of the salt affected soils occur in the deep and medium black soils regions. Of the salt affected vertisols, around 0.54 Mha land is spread in Maharashtra, 0.12 Mha in Gujarat state and 0.034 Mha in Madhya Pradesh (Nayak et al., 2003). Due to salt concentration and water logging of Vertisols, the productive soil is converted into unproductive one and causing a great economical loss (Postel, 1999). The best example is that of sugarcane in Maharashtra as the productivity of sugarcane reduced from more than $150 \mathrm{t} \mathrm{ha}^{-1}$ during the initial stages of introduction of irrigation to 50-60 $\mathrm{t} \mathrm{ha}^{-1}$ after waterlogging and salinity of soil (Rathod et al., 2011). Therefore, the provision of drainage is essential in irrigated soils for its sustainable health and productivity. The methods adopted for reclaiming the salt affected and waterlogged soils are mainly surface and subsurface drainage systems. The sub-surface drainage with corrugated perforated PVC pipes is highly expensive (approximately Rs. 2,00,000 ha $\mathrm{ha}^{-1}$ for $10 \mathrm{~m}$ drain spacing) and may not be affordable to small and medium size farmers. The high initial cost of underground per- forated PVC pipe drainage resulted in few adopters of the drainage technology in vertisols. A viable alternate to pipe drainage could be mole drainage which is a pipeless and trenchless drainage system. Dhakad et al. (2014) studied effect of mole drainage on the growth parameters \& productivity of soybean in various mole drains treatments were found better in comparison with control. In India, most of the studies related to mole drainage were carried out under laboratory conditions and studies under actual field conditions are limited. This may be due to the unavailability of properly designed mole plough and high H.P. tractors (Kolekar et al., 2011). Ramana Rao (2006) conducted the mole drainage studies in temporarily waterlogged Vertisols under rainfed conditions at Bhopal (M.P.) and found that mole drain can be economically feasible and effectively used for drainage of Vertisols. Chickpeas are very sensitive to waterlogging and even if waterlogged for a short period of time, crop losses can be severe. Irrigation during flowering or pod filling stage when the crop is more sensitive further increases the risk of yield loss. It is, therefore both irrigation and drainage management is more important for chickpea (Lucy and Slatter, 2002). Considering the importance of the drainage of vertisols for improving the productivity of the irrigated agriculture and high cost associated with the pipe and frequent maintenance of open ditch drainage system, it was decided to test the performance of the mole drainage system and work out its economic 
feasibility for drainage of irrigated and waterlogged vertisols.

\section{MATERIALS AND METHODS}

Study area: The experiment was conducted during the year 2009-10 to 2011-12 at Challis Bigha farm (Survey No.155) of Agricultural Research Station (ARS), K. Digraj, Dist. Sangli (M.S.), India to study the performance of mole drainage and its economic feasibility for drainage of irrigated and waterlogged vertisols of Maharashtra. Formation of mole drains (pipe less drains) depends on the soil physical properties such as soil texture, liquid limit, bulk density and soil moisture content at moling depth. Therefore, these parameters were analyszed using the standard protocols (Baruah and Barthakur, 1997). The moisture content, clay content and bulk density of soil at moling depth were $26 \%, 58 \%$ and $1.32 \mathrm{gm} / \mathrm{cc}$, respectively. The mole plough developed by ARS, K. Digraj, Dist. Sangli and Pd. Dr. D. Y. Patil College of Agricultural Engg. and Technology, Talsande, Dist. Kolhapur consists of a leg of $1000 \times 250 \times 40 \mathrm{~mm}$ and a foot of $75 \mathrm{~mm}$ with $85 \mathrm{~mm}$ expander diameter. The mole plough had an attachment for a wheeled tractor with a three point linkage. An experimental layout of different mole spacings viz. mole drainage (MD) with $2 \mathrm{~m}\left(\mathrm{~T}_{1}\right), 4 \mathrm{~m}\left(\mathrm{~T}_{2}\right), 6 \mathrm{~m}$ mole spacing $\left(\mathrm{T}_{3}\right)$ and without drainage i.e. control $\left(\mathrm{T}_{4}\right)$ in a randomized block design with five replications. The mole drains were formed from outlet side to upstream side with longitudinal gradient of $1.5 \%$ during first week of January 2009. Four laterals of mole drains of each spacing were installed. After moling operation, short length $(0.6 \mathrm{~m}$ long) of PVC pipes of $80 \mathrm{~mm}$ in diameter were pushed up in each mole channel outlet for preventing the ends of channels from collapsing due to water erosion at the time of draining excess water. After installation of mole drains, the chickpea in Rabi season were grown for monitoring the performance of mole drainage and works out its economic feasibility in drainage of irrigated and waterlogged vertisols of Maharashtra. The agronomic practices and plant protection measures were common to all the treatments and carried out as per recommendations. The drain discharge was recorded after every irrigation from each mole drain treatments. The yield contributing parameters and yields were recorded after harvest of crop.

Statistical analysis: The three years data of yield and yield attributing parameters of chickpea were used for the pooled analysis and presented SE and CD under weighted and pooled mean (Panse et al., 1967).

\section{RESULTS AND DISCUSSION}

Yield attributing parameters of chickpea: The yield attributing parameters of chickpea viz. plant height and number of pods per plant were recorded the highest in MD with 4m mole spacing during 2009-10 and 201011; and $6 \mathrm{~m}$ in 2011-12 (Table 1). However, the MD with $4 \mathrm{~m}$ mole spacing performed at par with MD of 6 $\mathrm{m}$ mole spacing. Whereas, the weighted mean of plant height and number of pods per plant recorded highest under MD with $4 \mathrm{~m}$ mole spacng which was at par with MD with $6 \mathrm{~m}$ mole spacing. This might be due to optimum drainage $(7.82 \mathrm{~mm} /$ day $)$ in $4 \mathrm{~m}$ mole drains and

Table 1. Effect of mole drainage with different mole spacing on plant height and number of pods per plant of chickpea (Means of 5plants).

\begin{tabular}{|c|c|c|c|c|c|c|c|c|c|c|c|c|}
\hline \multirow[b]{2}{*}{ Treatments } & \multicolumn{4}{|c|}{ Plant height (cm) } & \multicolumn{4}{|c|}{ No. of pods per plant } & \multicolumn{4}{|c|}{$\begin{array}{c}\text { Weight of seeds per plant (gm/ } \\
\text { plant) }\end{array}$} \\
\hline & $\begin{array}{l}2009 \\
-10\end{array}$ & $\begin{array}{l}2010 \\
-11\end{array}$ & $\begin{array}{l}2011 \\
-12\end{array}$ & $\begin{array}{l}\text { Weighted } \\
\text { mean }\end{array}$ & $\begin{array}{l}2009 \\
-10\end{array}$ & $\begin{array}{l}2010 \\
-11\end{array}$ & $\begin{array}{l}2011 \\
-12\end{array}$ & $\begin{array}{l}\text { Weighted } \\
\text { mean }\end{array}$ & $\begin{array}{l}2009 \\
-10\end{array}$ & $\begin{array}{l}2010 \\
-11\end{array}$ & $\begin{array}{l}2011 \\
-12\end{array}$ & $\begin{array}{l}\text { Weightd } \\
\text { mean }\end{array}$ \\
\hline $\begin{array}{l}\mathrm{T}_{1}: \mathrm{MD} \text { with } 2 \mathrm{~m} \\
\text { Mole spacing }\end{array}$ & 33.08 & 31.40 & 39.00 & 32.71 & 20.40 & 22.40 & 49.80 & 23.57 & 4.28 & 5.40 & 11.00 & 5.41 \\
\hline $\begin{array}{l}\mathrm{T}_{2}: \text { MD with } 4 \mathrm{~m} \\
\text { Mole spacing }\end{array}$ & 35.00 & 34.00 & 41.40 & 35.09 & 28.20 & 27.20 & 58.80 & 29.81 & 8.40 & 8.20 & 14.60 & 8.01 \\
\hline $\begin{array}{l}\mathrm{T}_{3}: \text { MD with } 6 \mathrm{~m} \\
\text { Mole spacing }\end{array}$ & 34.86 & 33.80 & 42.20 & 34.99 & 25.12 & 24.60 & 68.20 & 27.87 & 6.40 & 6.40 & 15.20 & 7.03 \\
\hline $\mathrm{T}_{4}$ : control & 31.36 & 31.20 & 5.80 & 31.74 & 15.44 & 13.20 & 45.20 & 18.07 & 3.56 & 4.40 & 10.20 & 4.54 \\
\hline S.E.t & 1.25 & 0.88 & 2.07 & 0.48 & 1.90 & 1.58 & 4.42 & 0.83 & 0.43 & 0.36 & 0.95 & 0.19 \\
\hline C. D. at $5 \%$ & 3.86 & 2.70 & 6.40 & 1.39 & 5.86 & 4.88 & 13.61 & 2.39 & 1.33 & 1.11 & 2.93 & 0.54 \\
\hline
\end{tabular}

Table 2. Effect of mole drainage with different mole spacing on yield of chickpea.

\begin{tabular}{|c|c|c|c|c|}
\hline \multirow{2}{*}{ Treatments } & \multicolumn{4}{|c|}{ Chickpea Yield $\left(\mathrm{q} \mathrm{ha}^{-1}\right)$} \\
\hline & $2009-10$ & $2010-11$ & 2011-12 & Pooled mean \\
\hline $\mathrm{T}_{1}:$ MD with $2 \mathrm{~m}$ Mole spacing & 8.37 & 9.59 & 13.59 & 10.52 \\
\hline $\mathrm{T}_{2}:$ MD with $4 \mathrm{~m}$ Mole spacing & 16.23 & 14.87 & 23.10 & 18.07 \\
\hline $\mathrm{T}_{3}:$ MD with $6 \mathrm{~m}$ Mole spacing & 14.88 & 13.44 & 24.36 & 17.56 \\
\hline $\mathrm{T}_{4}:$ Control & 6.45 & 8.47 & 12.20 & 9.04 \\
\hline S. E.土 & 1.00 & 0.91 & 1.62 & 0.76 \\
\hline C. D. at $5 \%$ & 3.07 & 2.79 & 5.00 & 2.16 \\
\hline
\end{tabular}


Table 3. Economic feasibility of mole drainage for chickpea under irrigated and waterlogged vertisols.

\begin{tabular}{|c|c|c|c|c|c|}
\hline Treatments & $\begin{array}{l}\text { Total Cost } \\
\text { for MD } \\
\left(\text { Rs.ha }^{-1}\right.\end{array}$ & $\begin{array}{l}\text { Average yield of } \\
\text { chickpea for three } \\
\text { years }(2009-10 \text { to } \\
2011-2012)\left(\mathrm{q} \mathrm{ha}^{-1}\right) \\
\end{array}$ & $\begin{array}{l}\text { Increase in } \\
\text { average yield } \\
\text { over control } \\
\left.(\mathbf{q ~ h a})^{-1}\right) \\
\end{array}$ & $\begin{array}{l}\text { Additional gross } \\
\text { benefits over control } \\
\left(\text { Rs.ha }^{-1}\right) @ 3500 \text { Rs.q }\end{array}$ & $\begin{array}{l}\text { Additional } \\
\text { net benefits } \\
\text { over control } \\
\left(\text { Rs.ha }^{-1}\right) \\
\end{array}$ \\
\hline $\begin{array}{l}\text { T1-MD with } 2 \mathrm{~m} \\
\text { mole spacing }\end{array}$ & $2000 /-$ & 10.52 & 1.48 & $5180 /-$ & $3180 /-$ \\
\hline $\begin{array}{l}\text { T2- MD with } 4 \mathrm{~m} \\
\text { mole spacing }\end{array}$ & $1100 /-$ & 18.07 & 9.03 & $31605 /-$ & $30505 /-$ \\
\hline $\begin{array}{l}\text { T3- MD with } 6 \mathrm{~m} \\
\text { mole spacing }\end{array}$ & $900 /-$ & 17.56 & 8.52 & 29820/- & 28920/- \\
\hline T4- Control & -- & 9.04 & -- & -- & -- \\
\hline
\end{tabular}

Table 4. Drain discharge and drainage coefficient for different mole spacing.

\begin{tabular}{lc}
\hline Treatments & $\begin{array}{c}\text { Drainage coefficient } \\
\left(\mathbf{m m ~ d a y}^{-1}\right)\end{array}$ \\
\hline $\mathrm{T}_{1}:$ MD with $2 \mathrm{~m}$ Mole spacing & 27.62 \\
$\mathrm{~T}_{2}:$ MD with $4 \mathrm{~m}$ Mole spacing & 7.82 \\
$\mathrm{~T}_{3}:$ MD with $6 \mathrm{~m}$ Mole spacing & 4.00 \\
$\mathrm{~T}_{4}:$ Control & ---- \\
\hline
\end{tabular}

slightly slow drainage ( $4 \mathrm{~mm} /$ day) under MD with $6 \mathrm{~m}$ mole drains (Table 4). These plant height and number of pods per plant were recorded lowest under control plot which was at par with MD of $2 \mathrm{~m}$ mole spacing. This might be due to lack of drainage under control plot and excess drainage of irrigation water (27.62 $\mathrm{mm} /$ day) with closely spaced mole drains of $2 \mathrm{~m}$ (Table 4). Whereas, the weight of seeds per plant were recorded significantly highest in MD with $4 \mathrm{~m}$ mole spacing during 2009-10 and 2010-11; and $6 \mathrm{~m}$ in 201112 Further, it was observed that the weighted mean of weight of seeds per plant recorded significantly highest under MD with $4 \mathrm{~m}$ mole spacing and lowest under control. This might be due to optimum drainage under $4 \mathrm{~m}$ mole spacing and lack of drainage under control treatment. Kolekar et al. (2011) reported that the groundnut plant height ,number of branches per plant, number of pods per plant, weight of pods per plant and total yield of groundnut were highest in $4 \mathrm{~m}$ drain spacing followed by $6 \mathrm{~m}, 2 \mathrm{~m}$ and control and total yield in $4 \mathrm{~m}$ drain was $69.2 \%$ more than the control and similar results were also recorded in soybean crop by Ramana Rao (2006).

Yield of chickpea: It is revealed from Table 2 that the MD with $4 \mathrm{~m}$ mole spacing recorded the highest yield of chickpea during the year 2009-10 and 2010-11; and $6 \mathrm{~m}$ in 2011-12. However, the MD with $4 \mathrm{~m}$ mole spacing and $6 \mathrm{~m}$ mole spacing were significantly at par with each other during all the three year. Whereas, the pooled mean of chickpea yield was recorded highest under MD with $4 \mathrm{~m}$ mole spacing which was at par with $6 \mathrm{~m}$ mole spacing. This might be due to optimum drainage $(7.82 \mathrm{~mm} /$ day) in $4 \mathrm{~m}$ mole drains (Table 4). The pooled mean of chickpea yield was observed lowest under control and at par with MD with $2 \mathrm{~m}$ mole spacing. This might be due to lack of drainage under control plot and excess drainage of irrigation water (27.62 mm/day) from mole drains of $2 \mathrm{~m}$ mole spacing
(Table 4). This indicated that the MD with $4 \mathrm{~m}$ mole spacing performed the best in respect of yield and yield contributing parameters of chickpea. Christen et.al. (1995) conducted an experiment on mole drainage in Murrumbidgee Irrigation Area, New South Wales, Australia and observed that mole drains significantly reduced surface ponding and soil water logging, leading to a $9 \%$ increase in wheat yield following rice. However, excessive irrigation water loss through closely spaced drains during the irrigation event was a problem. Similar results were recorded by Ramana Rao (2006) under temporarily waterlogged Vertisols (Rainfed) at Central Institute of Agricultural Engineering, Bhopal (M.P.).Ramana Rao et al. (2009 and 2012) examined the impact of pipeless drainage on soil properties and on soybean growth in vertisol soils and confirmed the findings of the experiment. Dhakad et al. (2014) studied the effect of mole drain treatments on the growth parameters and productivity of soybean and they found that productivity of soybean was better in mole drain treatments as compared to control (without mole drain).

Economic feasibility of mole drainage in vertisols: The major cost involved in mole drain technology is the operating cost of tractor. The operating cost of mole drainage at 2, 4 and $6 \mathrm{~m}$ spacing of mole drains was around Rs.2000, 1100 and 900 per ha respectively. It is observed from Table 3 that the mean additional yield of chickpea during 2009-10 to 2011-12 under MD with $2 \mathrm{~m}, 4 \mathrm{~m}$ and $6 \mathrm{~m}$ mole spacings were recorded as $1.48,9.03$ and $8.52 \mathrm{q} \mathrm{ha}^{-1}$ respectively over control. It is, therefore, the additional gross benefits recorded under MD with $2 \mathrm{~m}, 4 \mathrm{~m}$ and $6 \mathrm{~m}$ mole spacings were Rs. 5180, 31605 and 29820 ha $^{-1}$ over control. The additional net benefits recorded by MD with $2 \mathrm{~m}, 4 \mathrm{~m}$ and $6 \mathrm{~m}$ were Rs.3180, 30505 and $28920 \mathrm{ha}^{-1}$ respectively over control. Hence, mole drainage with $4 \mathrm{~m}$ mole spacing is recommended for economically feasible production of chickpea under irrigated and waterlogged Vertisols. Similar results were recorded in soybean crop by Ramana Rao (2006) under temporarily waterlogged Vertisols (rainfed) at Central Institute of Agricultural Engineering, Bhopal (M.P.). Dhakad et al. (2014) found that the highest net returns from soybean were recorded in different mole drain spacing in comparison with control. This indicates the techno- 
economic feasibility of mole drainage in drainage of irrigated Vertisols.

\section{Conclusion}

The weighted means of yield attributing parameters of chickpea and pooled mean of chickpea yield recorded highest in MD with $4 \mathrm{~m}$ mole spacing and which was at par with $6 \mathrm{~m}$ mole drain spacing as compare to control plot (without mole drainage). The study clearly indicated that mole drainage with $4 \mathrm{~m}$ mole spacing is recommended for better productivity of chickpea and economically feasible under irrigated and waterlogged vertisols of Maharashtra.

\section{REFERENCES}

Baruah T.C. and Barthakur, H.P. (1997). A text book of soil analysis. Vikas Publishing House Pvt. Ltd., New Delhi.

Christen, E.W., Murlihead, W.A., Moll .J.L. and Spoor, G. (1995). First patent in 179 available now in the MIA, 1995. Farmers' newsletter large area no.145.

CSSRI (2007). Salinity Vision 2025. (Eds. Gurubachan Singh, Sharma, P.C., Kaledhonkar, M.J.), Central Soil Salinity Research Institute, Karnal, 116p.

Dhakad S.S., K.V. Ramana Rao, Vijay Agrawal and S.K. Verma (2014). Effect of different mole drain spacings on the growth characters and yield of soybean in Raisen district of MP. Research in Environment and Life Sciences, 7 (1): 23-25.

Kolekar O.L., Patil, S.A., Patil, S.B. and Rathod, S.D. (2011). Effect of different mole spacing on the yield of summer groundnut. International Journal of Agricul- tural Engineering, 04: 82-85.

Lucy, M. and Slatter, J. (2002). Irrigated Chickpea Management - Field Experiences. Australian Cotton Grower March-April

Nayak, A.K., Chinchmalatpure, A.R., Khandelwal, M.K., Rao, G.G. and Tyagi, N.K. (2003). Soil and Water Resources and Management Options for the Bara Tract under Sardar Sarovar Canal Command: A Critical Appraisal. Status Paper No.1, Central Soil salinity Research Institute, Regional Research Station, Bharuch, Gujarat.

Panse, V.G. and Sukhatme, P.V. (1967). Statistical methods for Agric. Workers. II Enlarged Edn. ICAR, New Delhi.

Postel, S.L. (1999). Pillar of Sand: Can the irrigation miracle last?" W. W. Norton, New York.

Ramana Rao K.V., and Ramadhar Singh (2012). Pipe Less Drainage (Mole Drainage) Studies Under Actual Farmers' Field Conditions - A Case Study in India. Proceeding of $11^{\text {th }}$ ICID International Drainage Workshop on Agricultural Drainage Needs and Future Priorities Pyramisa Hotel, Cairo, Egypt, September 23-27 (Paper No.35): 1-6.

Ramana Rao K.V., Ravi Kishore and Ramadhar Singh.(2009). Mole drainage to enhance soybean production in waterlogged Vertisols . Journal of Agricultural Engineering, 46: 54-58.

Ramana Rao (2006). Principles of mole drainage and its economical feasibility in drainage of vertisols, CIAE Bhopal.Pp.144-148.

Rathod, S.D., Gorantiwar, S.D., Dahiwalkar, S.D., Kamble, B.M., Patil, S.B. and Kathmale, D.K. (2011). Performance and economic feasibility of mole drainage in irrigated vertisols. Journal of Soil Salinity and Water Quality, 3 (1): 37-40. 